Article

\title{
Comparative Evaluation of Integrated Waste Heat Utilization Systems for Coal-Fired Power Plants Based on In-Depth Boiler-Turbine Integration and Organic Rankine Cycle
}

\author{
Shengwei Huang ${ }^{1}$, Chengzhou Li ${ }^{1}$, Tianyu Tan ${ }^{1}$, Peng Fu ${ }^{2}$, Ligang Wang ${ }^{3, *}$ \\ and Yongping Yang ${ }^{1}$ \\ 1 National Research Center for Thermal Power Engineering and Technology, North China Electric Power \\ University, Changping district, Beijing 102206,China; china_hsw@163.com (S.H.); \\ chengzhou_li@163.com (C.L.); tantianyu1229@126.com (T.T.); yyp@ncepu.edu.cn (Y.Y.) \\ 2 Shenhua Guohua (Beijing) Electric Power Research Institute, Chaoyang district, Beijing 100025, China; \\ paulfp235@126.com \\ 3 Industrial Process and Energy Systems Engineering, Swiss Federal Institute of Technology in Lausanne, \\ Sion 1951, Switzerland \\ * Correspondence: lgwangeao@163.com; Tel.: +41-21-69-34208
}

Received: 7 November 2017; Accepted: 20 January 2018; Published: 29 January 2018

\begin{abstract}
To maximize the system-level heat integration, three retrofit concepts of waste heat recovery via organic Rankine cycle (ORC), in-depth boiler-turbine integration, and coupling of both are proposed, analyzed and comprehensively compared in terms of thermodynamic and economic performances. For thermodynamic analysis, exergy analysis is employed with grand composite curves illustrated to identify how the systems are fundamentally and quantitatively improved, and to highlight key processes for system improvement. For economic analysis, annual revenue and investment payback period are calculated based on the estimation of capital investment of each component to identify the economic feasibility and competitiveness of each retrofit concept proposed. The results show that the in-depth boiler-turbine integration achieves a better temperature match of heat flows involved for different fluids and multi-stage air preheating, thus a significant improvement of power output (23.99 MW), which is much larger than that of the system with only ORC (6.49 MW). This is mainly due to the limitation of the ultra-low temperature (from 135 to $75^{\circ} \mathrm{C}$ ) heat available from the flue gas for ORC. The thermodynamic improvement is mostly contributed by the reduction of exergy destruction within the boiler subsystem, which is eventually converted to mechanical power; while the exergy destruction within the turbine system is almost not changed for the three concepts. The selection of ORC working fluids is performed to maximize the power output. Due to the low-grade heat source, the cycle with R11 offers the largest additional net power generation but is not significantly better than the other preselected working fluids. Economically, the in-depth boiler-turbine integration is the most economic completive solution with a payback period of only 0.78 year. The ORC concept is less attractive for a sole application due to a long payback time (2.26 years). However, by coupling both concepts, a net power output of $26.51 \mathrm{MW}$ and a payback time of almost one year are achieved, which may promote the large-scale production and deployment of ORC with a cost reduction and competitiveness enhancement.
\end{abstract}

Keywords: coal-fired power plants; waste heat utilization; organic Rankine cycle; exergy analysis; in-depth boiler-turbine integration 


\section{Introduction}

Coal-fired power generation plays a decisive role in the power generation sector in China and is significant to ensure secure electricity supply. Currently, coal-fired power plants contribute around $57 \%$ of the total installed power capacity ( 1.65 billion $\mathrm{kW}$ ) by the end of 2016 . In the last decade, China's government has imposed a policy of replacing small, non-efficient subcritical power plants with large, highly-efficient supercritical or even ultra-supercritical power plants, which employ very high steam pressure and temperature (over $25 \mathrm{MPa}$ and $600^{\circ} \mathrm{C}$ ). With such an effort, the specific coal consumption of coal-fired power plants in China has been reduced significantly, for example, $321 \mathrm{~g} / \mathrm{kWh}$ for plants over $600 \mathrm{MW}$ [1]. From the thermodynamic viewpoint, the above-mentioned reduction of specific coal consumption is mainly because of the development of high-temperature materials, which allow the Rankine cycle to operate at a very high average temperature of heat absorption [2-7]. It is also concluded that the system designs of modern large-scale plants still follow those of backward small-scale plants and limited performance improvement has been achieved from system-level heat integration viewpoint $[1,8]$. The system design of thermal power plants faces a severe requirement of theory and technology innovation to achieve deep energy conservation, considering varying coal quality, complex operating boundary, peak-shaving responsibility and the requirement of ultra-low pollutant emissions [9-13].

Waste heat utilization system (WHUS) is one of the most effective approaches to deeply reduce the exergy losses from boiler and turbine cold-ends, which can result in an improvement of overall system efficiency and a reduction of pollutant emissions [14-18]. There are three main methods with respect to different sources of waste heat and levels of system integration: (1) direct recovery of low-temperature heat from the exhausted flue gas via Organic Rankine Cycle (ORC) [19-21] or $\mathrm{CO}_{2}$ cycle [22]; (2) utilization of ultra-low-temperature heat in the exhausted steam via heat pump for district heating [23,24]; and (3) deep coupling the turbine and boiler subsystems via low-pressure economizer (LPE) [25-27] to enhance the utilization of low- and intermediate-temperature heat within the whole system [28]. The first two approaches bring minimal modifications on the original system layouts and can be easily implemented to existing power plants; however, the third approach is more complicated due to the redesign of the layouts of both boiler and turbine cold-ends. Additionally, due to the locations and temperature levels involved in the first and third approaches, certain synergy may exist and may lead to a further enhanced energy-saving effect.

An ORC system employs organic working fluids with phase change occurring at low temperature, thus can utilize low-temperature waste heat to produce vapor and superheated gas. The ORC technology has attracted increasing attention and has been gradually employed in practical industrial applications. For example, Compana et al. [29] estimated the feasibility of installing ORC units in different industries over $27 \mathrm{EU}$ countries and demonstrated its potential for energy savings and environmental benefits. For practical applications, Cavazaini and Toso [30] conducted a techno-economic feasibility analysis for the integration of a small-scale commercial ORC in a real case study. Pierobon et al. [31] employed a multi-objective optimization approach to identify suitable waste heat recovery technologies for existing and future offshore facilities and concluded that ORC presented better performance than steam Rankine cycle and air bottoming cycle.

Key issues regarding the design and operation of ORC systems [32] have been investigated, e.g., working-fluid selection [33-35], optimal system design for efficiency improvement [35,36] and optimal system control and operation [37]. For working-fluid selection, Hung [38] investigated the effects of different dry fluids on the ORC performance and showed that the irreversibility depended on the type of heat sources. Cavazzini et al. [39] conducted thermodynamic optimization of a sub-critical ORC for heat sources with the temperature level between 80 and $150{ }^{\circ} \mathrm{C}$ to choose the optimal fluid from a list of 37 candidates. Pezzuolo et al. [40] performed the fluid selection among 81 possible candidates. For optimal system design and operation, Kermani et al. [35] proposed an approach for integrated design of ORC process and working fluid using PC-SAFT. Branchini et al. [41] performed a systematic thermodynamic comparison of ORC configurations considering various performance 
indicators. Li et al. [34] provided insights on the system design based on pinch analysis and identified the effects of pinch-point temperature difference (PPTD) in evaporator and condenser of subcritical ORCs on the electricity production cost (EPC). Stoppato [42] thermo-economically analyzed different operating models and offered some guidelines for selecting appropriate incentive of a reference plant sited in Asiago. Further considering the flexibility, safety and less maintenance requirement [32], a basic ORC system is considered for designing an integrated waste heat recovery system for modern coal-fired power plants.

The redesign of the layouts of both boiler and turbine cold-ends, by innovative concepts for system-level heat integration and novel design of heat exchangers working under bad flue gas conditions [43-47], has been emerging in recent years [48,49]. The key idea of such a system-level heat integration is to equip low-temperature economizers (LTE) after or parallel to the air preheat to recover the waste heat from the flue gas, thus suppressing steam extractions for feedwater regeneration $[50,51]$. In such a way, in-depth recovery of low-temperature waste heat can be achieved. From thermodynamic viewpoint, the fundamental purpose of this approach is introducing the stream splitting to flexibly adjust the heat capacities of the involved heat streams, thus debottlenecking the temperature mismatch of heat integration $[52,53]$. With the splitting of flue gas, temperature levels of hot and cold streams are better matched with multi-stage air preheating, which reduces the exergy destruction caused by heat transfer and boosts the power output. Several new technologies to recover low-grade heat from humid flue gas, including the latent heat of vapor condensation, have been investigated in $[54,55]$. Advanced waste heat recovery systems by dividing the air preheating procedure into high-temperature and low-temperature parts were evaluated in $[43,56]$, where the air heating at the low temperature is realized by the exhausted steam extraction and a low-temperature economizer is configured between the electrostatic precipitator and the low-temperature air preheater for feedwater preheating. Two waste heat recovery methods (replacement of regenerative feedwater heaters and implementation of an additional ORC unit) were evaluated in [57] from both thermodynamic and economic viewpoints. These concepts realize better heat cascade utilization at the system level. In our previous work [27], we have also demonstrated that the in-depth interaction between boiler and turbine cold-ends does contribute to a net power output increment of $13.68 \mathrm{MW}$ for a $1000 \mathrm{MW}$ coal-fired power plant.

In this paper, the potential synergies between the ORC and in-depth boiler-turbine integration are investigated to further enhance the system-level heat utilization, since part of the temperature levels are overlapped. The cascade utilization of heat from boiler and turbine cold-ends can be realized by strong heat-exchange interaction among various working fluids (flue gas, extracted steam, feed water, air and the organic working fluids). Three concepts are proposed for comparison purpose: (1) only in-depth boiler-turbine integration (as a follow-up of our previous research [27]); (2) only the ORC; and (3) coupling both the ORC and boiler-turbine interaction. These concepts are analyzed and compared from the energectic, exergetic and economic viewpoints with an emphasis on the third concept. For the ORC, preliminary screening and selection of working fluid for ORC are performed to ensure competitive performance for the available heat source. The paper is organized as follows: In Section 2, the basic power plant and the three proposed concepts are described. Then, in Section 3, the methods employed for working-fluid selection and system evaluation are introduced. Subsequently, in Section 4, the working-fluid selection is first discussed with the influence on system performance and, afterwards, throughout discussion and comparison of all four cases are given. Finally, the conclusions are drawn in Section 5.

\section{Description of Case Studies}

The reference case of the original power plant and the cases with only in-depth boiler-turbine interaction, only ORC, and the coupling of both concepts are introduced with specific specifications, respectively.

\subsection{The Reference Coal-Fired Power Plant}

A typical $1000 \mathrm{MW}$ ultra-supercritical power plant in China is selected as the reference case to quantify the potential of waste heat recovery from the exhausted flue gas. The net power output of the 
selected power plant is $994 \mathrm{MW}$ with the pressure/temperature of main steam of $26.01 \mathrm{MPa} / 600{ }^{\circ} \mathrm{C}$ and the temperature of reheated steam of $600{ }^{\circ} \mathrm{C}$. The power plant is designed for a bituminous coal with the element analysis of $57.37 \%$ carbon, $4.19 \%$ hydrogen, $7.57 \%$ oxygen, $1.4 \%$ nitrogen, $0.87 \%$ sulfur and 7.3\% moisture. The stream data related to all regenerative heats (RHs) have been listed in Table 1 for the turbine heat rate acceptance (THA) condition, under which the inlet conditions and back pressure of the turbine are nominal with the regenerative feedwater preheaters operating normally. More detailed descriptions of $1000 \mathrm{MW}$-level coal-fired power plants can be found elsewhere in our publications, e.g., [58-63], and will not be repeated here.

Table 1. Major stream data for the turbine heat rate acceptance (THA) condition.

\begin{tabular}{cccccccccc}
\hline Item & Unit & RH1 & RH2 & RH3 & DEA & RH5 & RH6 & RH7 & RH8 \\
\hline Temperature of steam extraction & ${ }^{\circ} \mathrm{C}$ & 421.8 & 339.6 & 505.4 & 396.5 & 326.0 & 252.9 & 170.1 & 95.7 \\
Pressure of steam extraction & $\mathrm{MPa}$ & 8.13 & 4.54 & 2.28 & 1.11 & 0.64 & 0.36 & 0.17 & 0.08 \\
Temperature of outgoing feedwater & ${ }^{\circ} \mathrm{C}$ & 295.7 & 256.1 & 217.6 & 186.9 & 156.6 & 135.2 & 110.4 & 87.9 \\
Pressure of outgoing feedwater & $\mathrm{MPa}$ & 27.87 & 27.88 & 27.89 & 1.04 & 1.05 & 1.06 & 1.07 & 1.08 \\
Temperature of incoming feedwater & ${ }^{\circ} \mathrm{C}$ & 256.1 & 217.6 & 186.9 & 156.6 & 135.2 & 110.4 & 87.9 & 38.6 \\
Pressure of the incoming feedwater & $\mathrm{MPa}$ & 27.88 & 27.89 & 27.90 & 1.05 & 1.06 & 1.07 & 1.08 & 1.09 \\
Temperature of the drainage & ${ }^{\circ} \mathrm{C}$ & 261.7 & 223.2 & 192.5 & - & 140.8 & 116.0 & 93.5 & 44.2 \\
\hline
\end{tabular}

\subsection{The Case with In-Depth Boiler-Turbine Integration}

For current regenerative systems of coal-fired power plants, a large amount of steam at various pressure levels are extracted to heat the feedwater and condensate water, which improves the average temperature of heat absorption of the Rankine cycle, thus enhancing the thermodynamic efficiency. However, the working ability of the extracted steam will not be fully realized. The proposed integrated system (modified from [27]) aims at utilizing waste heat from the boiler cold-end to partially heat the feedwater so that some of the steam extraction can be avoided to boost the power generation and system efficiency without introducing additional heat sources.

Figure 1 illustrates the configuration of the integrated WHUS system with in-depth boiler-turbine integration. A bypass flue gas duct parallel to the main air-preheater duct is introduced with two-stage successively-configured gas-water heat exchangers. Approximately one-third of the total flue gas out of the economizer enters the newly introduced bypass duct and sequentially exchanges heat in the high-temperature and low-temperature gas-water heat exchangers (HGHE and LGHE). Since the heat of the flue gas entering the main duct decreases and cannot meet the heat requirement for air preheating, two additional heat exchangers (FSHE and SSHE) are introduced for air preheating at low temperatures with the low-grade heat from the low-pressure steam extraction and the flue gas. The specifications of the main heat exchanges involved are presented in Table 2.

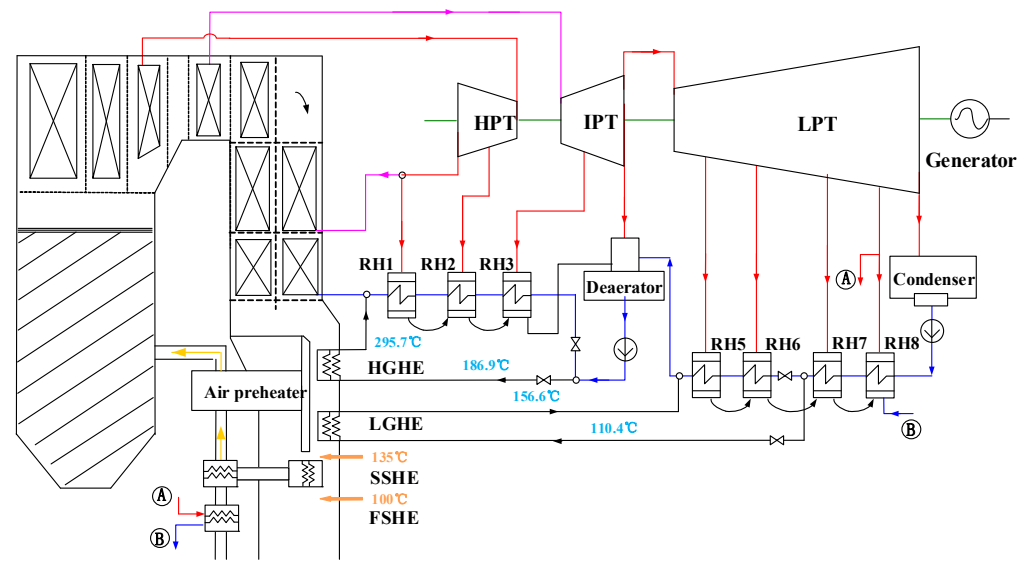

Figure 1. Schematic of the case with in-depth boiler-turbine interaction. 
As given in Table 2, by employing two additional heat exchangers (SSHE and FSHE), the logarithmic mean temperature difference of the whole air preheating process is controlled above $35{ }^{\circ} \mathrm{C}$. Particularly, by introducing the one-third of the flue gas cooled from $385^{\circ} \mathrm{C}$ down to $135^{\circ} \mathrm{C}$ for feedwater preheating, parts of the first, second, third, fifth and sixth-stage steam extractions are saved and continue for expansion, thus leading to remarkable performance enhancement.

Table 2. Specifications of the main heat exchangers involved.

\begin{tabular}{cccccc}
\hline Item & Unit & HGHE & LGHE & FSHE & SSHE \\
\hline Inlet temperature of flue gas & ${ }^{\circ} \mathrm{C}$ & 385 & 196 & - & 135 \\
Outlet temperature of flue gas & ${ }^{\circ} \mathrm{C}$ & 196 & 135 & - & 100 \\
Inlet temperature of water/steam & ${ }^{\circ} \mathrm{C}$ & 186.9 & 110.4 & $95.4\left(11^{*}\right)$ & - \\
Outlet temperature of water/steam & ${ }^{\circ} \mathrm{C}$ & 295.7 & 156.6 & $95.4\left(0^{*}\right)$ & - \\
Inlet temperature of air & ${ }^{\circ} \mathrm{C}$ & - & - & 20 & 60 \\
Outlet temperature of air & ${ }^{\circ} \mathrm{C}$ & - & - & 60 & 100 \\
Logarithmic mean temperature difference & ${ }^{\circ} \mathrm{C}$ & 35.13 & 31.40 & 46.29 & 37.03 \\
Heat exchanger area & $\mathrm{m}^{2}$ & 30,847 & 12,895 & 15,061 & 29,576 \\
\hline
\end{tabular}

* Steam quality: dryness.

This proposed system utilizes part of the waste heat from the exhausted flue gas with its temperature reducing from around $130{ }^{\circ} \mathrm{C}$ in the original design to $100{ }^{\circ} \mathrm{C}$, due to the limitation of acid dew point of the flue gas, $t_{\mathrm{adp}}$. There are many methods to estimate the acid dew point [64]. Considering the acceptable deviation among various methods, the acid dew point is calculated here with the widely-employed method in China [65,66]:

$$
t_{\mathrm{adp}}=t_{\mathrm{wdp}}+\frac{\beta \cdot\left(S_{\mathrm{ar}, \mathrm{zs}}\right)^{1 / 3}}{1.05^{\left(\alpha_{\mathrm{ash}} \cdot A_{\mathrm{ar}, \mathrm{zs}}\right)}}
$$

where $t_{\mathrm{wdp}}$ is the dew point temperature of water with the corresponding water vapor pressure of the flue gas $\left({ }^{\circ} \mathrm{C}\right), \beta$ is the coefficient related to the excess air coefficient $(\beta=121)$ [67], $S_{\mathrm{ar}, z \mathrm{~s}}$ and $A_{\mathrm{ar}, \mathrm{zs}}$ are the sulfur and ash content at as-received basis $(\mathrm{kg} / \mathrm{kcal})$, and finally the $\alpha_{\text {ash }}$ is the fly-ash share in the fuel gas (0.9) [67]. Due to the relatively low sulfur content of the coal (approximately $0.87 \%$ ), the acid dew point is estimated as $94.7^{\circ} \mathrm{C}$, which indicates that the outlet flue gas temperature of the novel WHUS can be reduced to $100{ }^{\circ} \mathrm{C}$ without serious corrosion problem.

\subsection{The Case with ORC for Waste Heat Recovery}

Since the in-depth boiler-turbine integration requires significant modification on the real equipment, the decision makers of existing power plants can hardly accept such a complex proposal due to potential risks and influences on the system reliability. Therefore, a simple end-of-pipe waste heat recovery system via ORC without any influence on the existing power plants (Figure 2) might be easier to be accepted.

The WHUS via ORC employs a two-stage evaporator to recover the waste heat from flue gas, which is deployed between the electrostatic precipitator (ESP) and flue-gas desulfurization unit (FGD), and between the air preheater and the ESP, respectively. Evaporator 1 recovers waste heat from the flue gas between $100{ }^{\circ} \mathrm{C}$ to $130{ }^{\circ} \mathrm{C}$. Evaporator 2 employs fluoroplastic heat exchanger technology [68] to eliminate the corrosion problem, which allows further reduction of flue-gas temperature down to $75^{\circ} \mathrm{C}$ without affecting the operating efficiency of the FGD.

The ORC system without regenerating process has been considered, since the recuperative preheating does not always lead to the maximization of net additional power output [39]. In the ORC-evaporator (ORCE), the high-pressure, sub-cooled liquid-phase working fluid is vaporized and is then expanded in the ORC-turbine (ORCT) for power generation. The expanded superheated vapor 
is cooled down and condensed to the saturated liquid state in the condenser (ORCC). Afterwards, the liquid-phase working fluid is pumped to the evaporator for heat absorption.

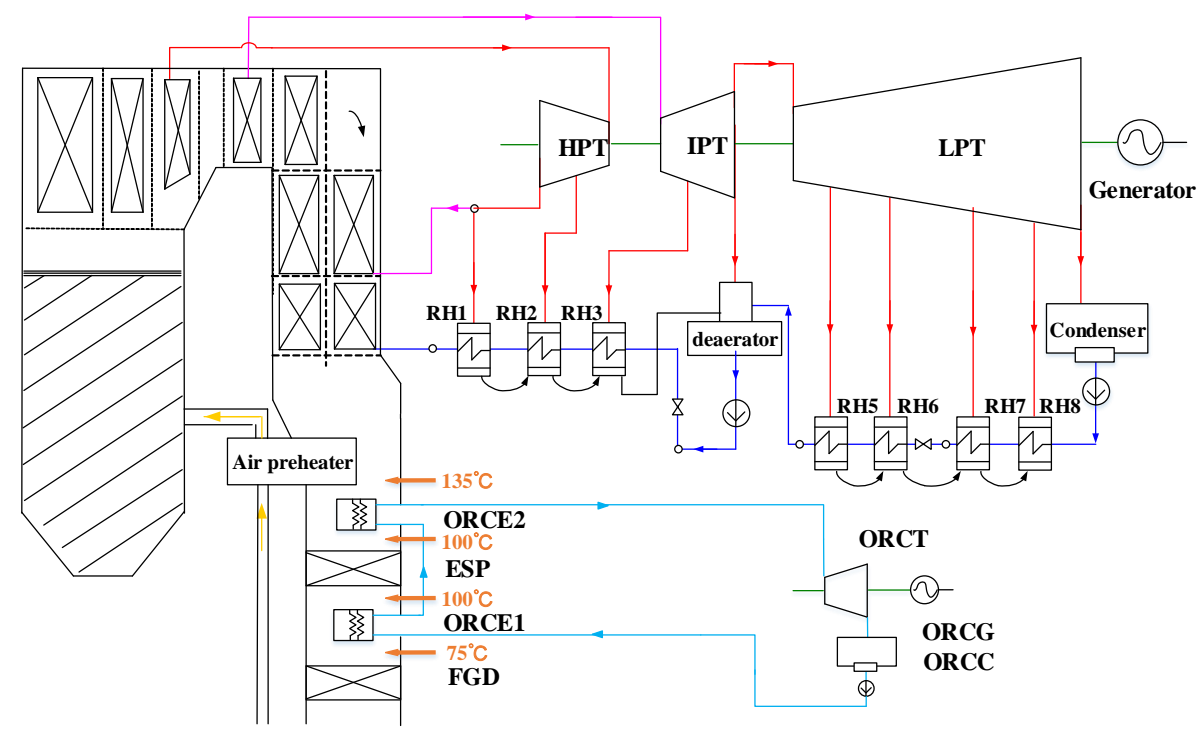

Figure 2. Schematic of the case with end-of-pipe waste heat utilization via ORC.

\subsection{The Case with In-Depth Boiler-Turbine Integration and ORC}

The concept considering both in-depth boiler-turbine integration and ORC is mainly for more advanced, integrated plant design and aims at a further performance enhancement compared with the cases described above. The system layout is illustrated in Figure 3 with the SSHE employed for air preheating, which indicates that only one evaporator is employed for the heat absorption of the ORC, compared with Figure 2. The flue-gas temperature entering the ESP and FGD are the same as those of the ORC WHUS.

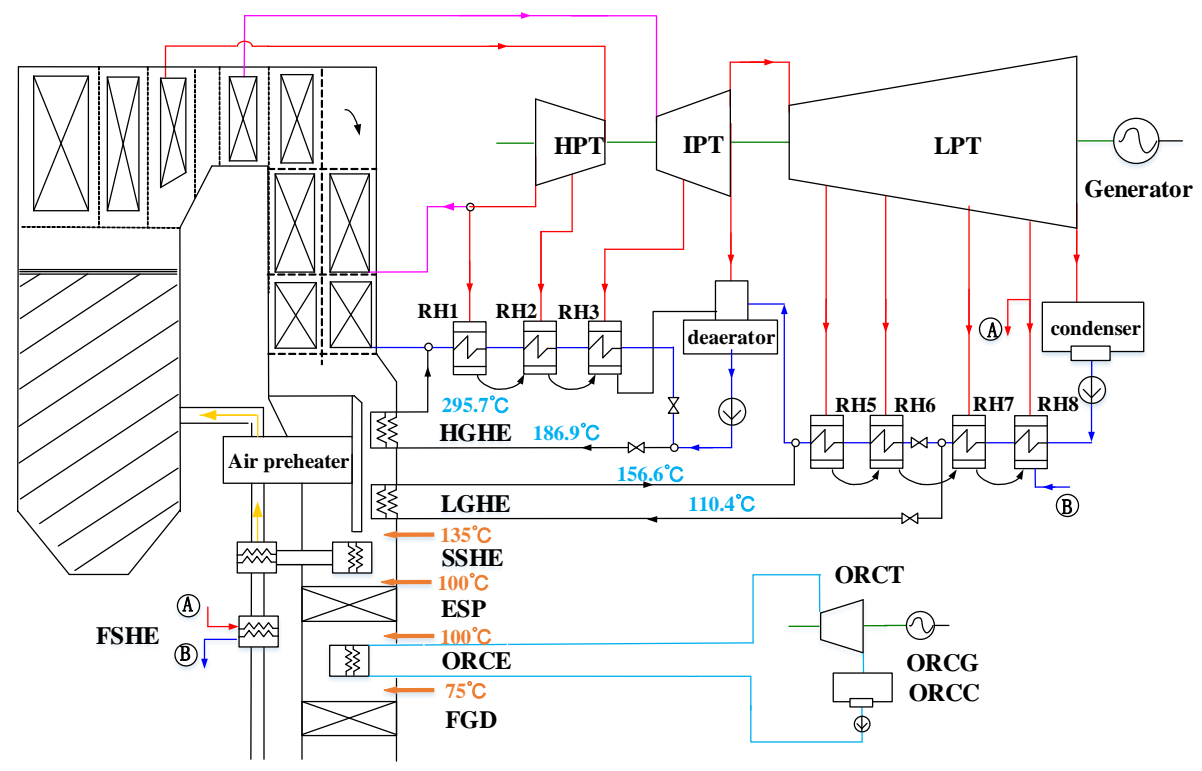

Figure 3. Schematic of the integrated case with both in-depth boiler-turbine integration and ORC. 


\section{Methodology}

The simulations of all concepts described in the last section are performed by Ebsilon Professional 13 [69]. Since the performance of the involved ORC is largely affected by the selected organic working fluid for given heat source, the ORC working fluid and the corresponding evaporating and condensing pressures are first selected with genetic algorithm (GA) to maximize the power generation of ORC. Then, exergetic and economic evaluation methods are described for thermo-economic comparison of the four different cases (including the reference case).

\subsection{Working Fluid Selection of ORC}

For the given heat-source temperature, a pre-selection of working fluids is performed based on [32]. Eight working fluids, i.e., R134A, Pentane, RC318, R236FA, R245FA, R123, R141B and R11, are to be evaluated. It should be mentioned that here we focus on the thermo-economic evaluation; therefore, other criteria, e.g., safety, technological feasibility and environmental harmony, are not considered. For each working fluid, the genetic algorithm is employed to optimize the two operating pressures of the ORC. The maximum allowed evaporating pressure is selected by the heat-source temperature $T_{\mathrm{s}, \text { in }}$ and the approach temperature difference $\Delta T_{\min }$ (see Figure 4, set as $10^{\circ} \mathrm{C}$ [41]). The pinch-point temperature difference (PPTD) is set as $5^{\circ} \mathrm{C}$ [41]. Note that these two temperature differences are fixed, since only thermodynamic but not economic objective is considered here.

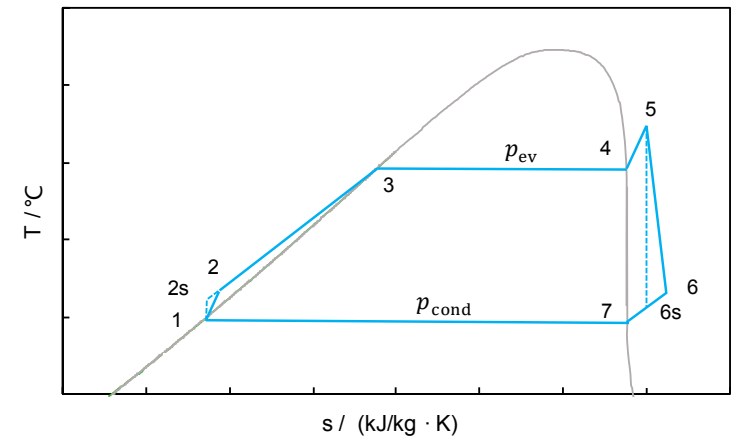

(a)

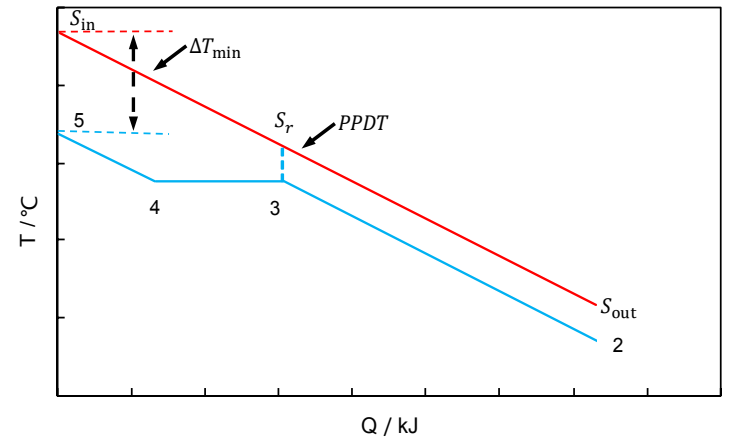

(b)

Figure 4. Illustrative T-s diagram (a); and T-Q diagram (b) of a sub-critical ORC $\left(T_{\mathrm{s}, \text { in }}\right.$-inlet temperature of the flue gas, $T_{\mathrm{S}, \text { out }}$-outlet temperature of the flue gas, $T_{\mathrm{s}, \mathrm{r}}$ - the temperature of the flue gas at the PPTD point, $T_{\mathrm{c}, \text { out }}$-outlet temperature of the cooling water, $T_{\mathrm{c}, \text { in }}$-inlet temperature of the flue gas, $T_{\mathrm{c}, \mathrm{r}}$ - the temperature of the cooling water at the PPTD point, $p_{\mathrm{ev}}$-evaporating pressure, $p_{\text {cond }}$-condensation pressure).

The thermodynamic model of the sub-critical ORC is classical [39]:

(1) ORC Evaporator

$$
\begin{gathered}
\dot{m}_{\mathrm{wf}}\left(h_{5}-h_{2}\right)=\dot{m}_{\mathrm{s}}\left(h_{\mathrm{s}, \text { in }}-h_{\mathrm{s}, \text { out }}\right)=\dot{Q}_{\text {evap }} \\
\dot{m}_{\mathrm{wf}}\left(h_{5}-h_{3}\right)=\dot{m}_{\mathrm{s}}\left(h_{\mathrm{s}, \text { in }}-h_{\mathrm{s}, \mathrm{r}}\right),
\end{gathered}
$$

where the $\dot{Q}_{\text {evap }}$ is the heat transferred in the ORC evaporator, $\dot{m}_{\mathrm{wf}}$ is the mass flow of the organic working fluid, $\dot{m}_{\mathrm{S}}$ is the mass flow of the heat source (flue gas).

(2) ORC Turbine

$$
\begin{gathered}
\eta_{\mathrm{ORCT}}=\left(h_{5}-h_{6}\right) /\left(h_{5}-h_{6 \mathrm{~s}}\right), \\
\dot{W}_{\mathrm{ORCT}}=\dot{m}_{\mathrm{wf}}\left(h_{5}-h_{6}\right),
\end{gathered}
$$

where the $\dot{W}_{\mathrm{ORCT}}$ is the power output of the ORC turbine and $\eta_{\mathrm{ORCT}}$ is the isentropic efficiency of the ORC turbine (88\% [70]). 
(3) ORC Condenser

$$
\begin{gathered}
\dot{m}_{\mathrm{wf}}\left(h_{6}-h_{1}\right)=\dot{m}_{\mathrm{c}}\left(h_{\mathrm{c}, \text { out }}-h_{\mathrm{c}, \text { in }}\right)=\dot{Q}_{\mathrm{cond}}, \\
\dot{m}_{\mathrm{wf}}\left(h_{7}-h_{1}\right)=\dot{m}_{\mathrm{c}}\left(h_{\mathrm{c}, \mathrm{r}}-h_{\mathrm{c}, \text { in }}\right)
\end{gathered}
$$

where the $\dot{Q}_{\text {cond }}$ is the heat transferred in the ORC condenser and $\dot{m}_{\mathrm{c}}$ is the mass flow of the cooling water.

(4) ORC Pump

$$
\begin{gathered}
\eta_{\mathrm{ORCP}}=\left(h_{2 \mathrm{~s}}-h_{1}\right) /\left(h_{2}-h_{1}\right), \\
\dot{W}_{\mathrm{ORCP}}=\dot{m}_{\mathrm{wf}}\left(h_{2}-h_{1}\right),
\end{gathered}
$$

where the $\dot{W}_{\text {ORCP }}$ is the power consumed by the ORC pump and $\eta_{\text {ORCP }}$ is the isentropic efficiency of the ORC pump (80\% [70]).

The pressure drops as well as heat losses are neglected for all ORC equipment [39]. The net power output $\left(\dot{W}_{\mathrm{ORC}}\right)$ of the ORC is given as below:

$$
\dot{W}_{\mathrm{ORC}}=\dot{W}_{\mathrm{ORCT}}-\dot{W}_{\mathrm{ORCP}}-\dot{W}_{\mathrm{ORCC}}
$$

where $\dot{W}_{\text {ORCC }}$ is the power consumed by the recycle cooling water pump, which is calculated with the inlet temperature of the cooling water of $20^{\circ} \mathrm{C}$.

The optimization procedure for working-fluid selection and the corresponding operating variables is illustrated in Figure 5.

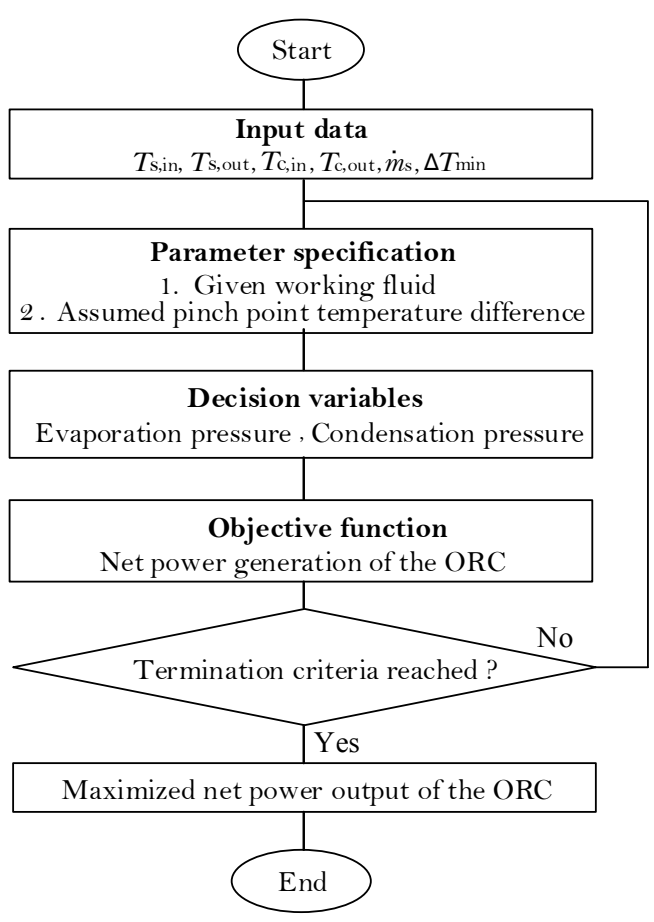

Figure 5. Simplified flow chart of the optimization procedure.

\subsection{Exergy Analysis}

Exergy analysis is employed in this paper to explore the difference in the energy utilization of the four cases. Exergy analysis can identify the sources and the magnitudes of exergy destructions and losses of energy systems [71-73], thus highlighting the processes with the largest exergy destruction or loss as the key components or processes for potential system improvement $[1,74-76]$. Note that the 
exergy losses do not occur at a single component level but only at the overall system level, when the system is interacting with the environment via vent streams.

The exergy balance of the component $k$ can be calculated as following formulation [77]:

$$
\dot{E}_{\mathrm{D}, k}=\dot{E}_{\mathrm{F}, k}-\dot{E}_{\mathrm{P}, k}
$$

where the symbols $\dot{E}_{\mathrm{F}, k} \dot{E}_{\mathrm{P}, k} \dot{E}_{\mathrm{D}, k}$ represent the fuel exergy, product exergy and exergy destruction, respectively. With the clear definitions of fuel exergy, product exergy, the exergy efficiency of a productive component $k$ can be expressed as:

$$
\varepsilon_{k}=\dot{E}_{\mathrm{P}, k} / \dot{E}_{\mathrm{F}, k}=1-\dot{E}_{\mathrm{D}, k} / \dot{E}_{\mathrm{F}, k}
$$

The exergy balance equation of the overall system can be formulated as below:

$$
\dot{E}_{\mathrm{F}, \text { tot }}=\dot{E}_{\mathrm{P}, \text { tot }}+\sum \dot{E}_{\mathrm{D}, k}+\dot{E}_{\mathrm{L}, \text { tot }}
$$

with the total exergy efficiency of the overall system defined as

$$
\varepsilon_{\mathrm{tot}}=\dot{E}_{\mathrm{P}, \mathrm{tot}} / \dot{E}_{\mathrm{P}, \text { tot }}
$$

The detailed calculation procedure of chemical and physical exergies about various material flows, work and heat streams can be referred in the literature [78]. The chemical exergy of coal also calculated as the product of the higher heating value (HHV) with a constant, usually 1.02 [77]. In addition, the reference environment for chemical exergy calculation is defined at $298.15 \mathrm{~K}$ and 1.098 bar [77].

\subsection{Economic Analysis}

Basic economic assumptions employed are listed as follows: (1) The on-grid power tariff is set as $0.061 \mathrm{USD} / \mathrm{kWh}$ and the annual full-load operating hours (e.g., the annual utilization hours) are assumed as $5000 \mathrm{~h}$, which indicates that the average operating load factor is below $100 \%$ due to the frequent participation in peak load regulation of large-scale coal-fired power units; (2) The auxiliary cost is fixed as $15 \%$ of the bare module cost for all components [79], which indicates a common total module factor $\left(f_{\mathrm{TM}}\right)$ of 0.15 ; (3) The operation and maintenance cost $\left(C_{\mathrm{O} \& \mathrm{M}}\right)$ accounts for $4 \%$ of the annualized total capital investment (TCI) [24,80]; (4) The exchange rate of RMB to U.S. dollar is set as $6.25 \mathrm{CNY} / \mathrm{USD}$.

\subsubsection{Estimation of Purchased Equipment Cost}

The total capital investment of a component can be estimated based on its purchased equipment cost (PEC) $[26,81]$, which is employed for the estimation of the corresponding bare module cost $\left(C_{\mathrm{BM}}\right)$ by further considering a bare module factor $\left(f_{\mathrm{BM}}\right)$ due to the selection of material, the operating temperature and pressure, etc. Thus, for this retrofit problem, the total capital investment cost can be calculated as follows:

$$
\mathrm{TCI}=\sum_{i} C_{\mathrm{TM}, i}=\sum_{i} C_{\mathrm{BM}, i}\left(1+f_{\mathrm{TM}}\right)=\sum_{i} P E C_{i} f_{\mathrm{BM}}\left(1+f_{\mathrm{TM}}\right) .
$$

The purchased equipment cost of a component can be estimated by a simple widely-used scaling method [81,82], if not many investment data are available for the considered component type:

$$
P E C_{i}=P E C_{\text {ref }}\left(\frac{S}{S_{\text {ref }}}\right)^{\alpha}
$$

where the symbols $S$ and $\alpha$ denote the selected sizing parameter and scaling factor, respectively, while the $P E C_{\text {rerf }}$ and $S_{\text {ref }}$ represent the reference capital investment and scaling parameter of the 
reference component, respectively. If there have been many investment data available for different sizes of the investigated component, the interested purchased equipment cost can be simply regressed with respect to the sizing parameters. For example, the PEC of heat exchangers (HEX), pump and turbine, can be estimated as follows [83,84]:

$$
\begin{gathered}
\log P E C_{\mathrm{HEX}}=K_{1}+K_{2} \log A+K_{3}(\log A)^{2} \\
\log P E C_{\mathrm{PUMP}}=K_{1}+K_{2} \log W+K_{3}(\log W)^{2} \\
\log P E C_{\mathrm{TURBINE}}=K_{1}+K_{2} \log W+K_{3}(\log W)^{2}
\end{gathered}
$$

where the co-efficients $K_{1}-K_{3}$ can be obtained by the regression and are 3.853, 0.424 and 0 for heat exchangers, 3.579, 0.321 and 0.003 for the pump, and 3.514, 0.598 and 0 for turbine [83]. For heat exchangers, pump and turbine, the sizing parameters are taken as area and shaft work, respectively. The bare module factor $\left(f_{\mathrm{BM}}\right)$ is generally a function of the material factor $\left(f_{\mathrm{M}}\right)$, the pressure factor $\left(f_{\mathrm{P}}\right)$, the temperature factor $\left(f_{\mathrm{T}}\right)$ as well as the actualization factor $\left(f_{\mathrm{A}}\right)$ as follows [82]:

$$
f_{\mathrm{BM}}=\mathcal{F}\left(f_{\mathrm{M}}, f_{\mathrm{P}}, f_{\mathrm{T}}, f_{\mathrm{A}}\right)
$$

The actualization factor is employed to convert the capital cost in the reference year to the actualization year, which can be based on different cost index, e.g., Marshall and Swift index (MS) and Chemical Engineering Plant Cost Index (CEPCI) [83].

For the system with only in-depth boiler-turbine integration, the TCI for retrofitting the original power plant mainly consists of the capital investment of the newly-added exchangers (HEX). The related capital investment is estimated based on the simple method (Equation (16)) with the reference cost data and all necessary factors given in Table 3. The bare module cost, in this case, is a product of all factors: $f_{\mathrm{BM}}=f_{\mathrm{M}} f_{\mathrm{P}} f_{\mathrm{T}} f_{\mathrm{A}}$.

Table 3. Reference cost data for newly-added heat exchangers.

\begin{tabular}{cccccccc}
\hline Component & $\begin{array}{c}\text { Reference Cost } \\
\left(\boldsymbol{P E C} \boldsymbol{C}_{\text {ref }}, \mathbf{M i l l i o n} \mathbf{\$}\right)\end{array}$ & $\begin{array}{c}\text { Sizing Parameter } \\
\left(\boldsymbol{S}_{\text {ref }}, \mathbf{m}^{\mathbf{2}}\right)\end{array}$ & $\begin{array}{c}\text { Scaling } \\
\text { Factor }(\boldsymbol{\alpha})\end{array}$ & $f_{\mathrm{M}}$ & $f_{\mathrm{P}}$ & $f_{\mathrm{T}}$ & $f_{\mathrm{A}}$ \\
\hline Heater & 0.693 & 13,149 & 0.68 & 1.00 & 1.00 & 1.20 & 1.08 \\
Air Preheater & 7.07 & 421,963 & 0.68 & 1.00 & 1.00 & 0.95 & 1.05 \\
\hline
\end{tabular}

For the case with only the ORC for waste heat recovery, the total capital investment comes from the evaporate, condenser, pump, and turbine, since the contribution of the fluid cost to the total investment cost is negligible, as shown in Refs. [34,42,83]. The costs of the evaporator and condenser are estimated by Equation (17) with the bare module factor obtained by [85]:

$$
f_{\mathrm{BM}}=\left(B_{1}+B_{2} f_{\mathrm{M}} f_{\mathrm{P}}\right)
$$

and the pressure factor formulated as

$$
\log F_{\mathrm{P}}=C_{1}+C_{2} \log p+C_{3}(\log p)^{2}
$$

The coefficients $B_{1}, B_{2}, C_{1}, C_{2}, C_{3}$ are $1.53,1.27,0,0$, and 0 for turbines and heat exchangers, 1.8, $1.51,0.168,0.348$ and 0.484 for pumps, respectively [83]. The costs of pumps and turbines are computed via Equations (18) and (19).

For the case with both ORC and in-depth boiler-turbine integration, the total capital investment is comprised of all newly-added heat exchangers (including the gas-air HEX, water-air HEX, ORC evaporator and condenser), pumps and turbines with the equations and coefficients listed above. 
With the total capital investment calculated for a specific retrofit, the annualized investment capital cost $\left(C_{\mathrm{TCI}}\right)$ can be calculated as $[81,82,86]$ :

$$
C_{\mathrm{TCI}}=\operatorname{TCI} \frac{i(1+n)^{i}}{(1+n)^{i}-1}
$$

where the symbol $i$ refers to the interest rate per year $(8 \%)$, while the $n$ represents the system lifespan (20 years).

\subsubsection{Economic Performance Indicators}

The feasibility of the three different retrofit concepts is further evaluated by an economic benefit, which is represented by the net annual revenue (NAR):

$$
N A R=E A I-C_{\mathrm{TCI}}-C_{\mathrm{O} \& \mathrm{M}}
$$

where the $E A I$ stands for the additional income per year of the overall plant after the specific retrofit:

$$
E A I=\Delta P_{\text {net }} \tau C_{\mathrm{e}}
$$

where the $\Delta P_{\text {net }}$ represents the net additional power output for the full-load operation of the plant after the retrofit, the $\tau$ is the equivalent full-load operation hours per year ( $5000 \mathrm{~h}$ as mentioned above), and the $C_{\mathrm{e}}$ stands for the tariff of the electricity sent to the grid.

In addition, the pay-back period $(\mathrm{Pt})$ for the total capital investment, a vital indicator to show the economic feasibility of a technology, is calculated as follows [87]:

$$
\mathrm{Pt}=-\log _{(1+\mathrm{i})}\left(1-\frac{T C I \cdot i}{E A I}\right)
$$

\section{Results and Discussion}

The three different retrofit concepts are comprehensively evaluated and discussed as follows: the selection of working fluid of the ORC, the comparison of the thermodynamic performances and the comparison of economic performances.

\subsection{The Selection of ORC Working Fluid}

Eight working fluids are screened in terms of the net additional power output with respect to two operating variables: the pressures of evaporation and condensation. The optimal operating

\begin{tabular}{|c|c|c|c|c|c|c|}
\hline Fluid & $\begin{array}{c}\text { Evaporation } \\
\text { Pressure (MPa) }\end{array}$ & $\begin{array}{l}\text { Condensation } \\
\text { Pressure (MPa) }\end{array}$ & $\begin{array}{c}\text { Mass Flowrate } \\
(\mathrm{kg} / \mathrm{s})\end{array}$ & $\begin{array}{l}\text { Pump Work } \\
\text { (MW) }\end{array}$ & $\begin{array}{l}\text { Turbine Output } \\
\text { (MW) }\end{array}$ & $\begin{array}{c}\text { ORC Net Power } \\
\text { Output (MW) }\end{array}$ \\
\hline R134A & 2.69 & 0.79 & 139.90 & 0.67 & 3.07 & 2.41 \\
\hline Pentane & 0.34 & 0.08 & 60.51 & 0.39 & 2.82 & 2.43 \\
\hline RC318 & 1.41 & 0.37 & 199.05 & 0.55 & 2.79 & 2.24 \\
\hline R236FA & 1.25 & 0.32 & 153.11 & 0.51 & 2.89 & 2.38 \\
\hline R245FA & 0.76 & 0.18 & 119.04 & 0.46 & 2.90 & 2.45 \\
\hline R123 & 0.46 & 0.11 & 134.74 & 0.44 & 2.92 & 2.48 \\
\hline R141B & 0.38 & 0.09 & 104.59 & 0.40 & 2.91 & 2.51 \\
\hline R11 & 0.48 & 0.13 & 132.57 & 0.41 & 2.93 & 2.52 \\
\hline
\end{tabular}
conditions of each working fluid are given in Table 4 for the system retrofitted with both the in-depth boiler-turbine integration and ORC.

Table 4. Optimal operating conditions and gains of the ORC with various working fluids.

From the perspective of the turbine output power, the R134A is the optimal fluid with $3.07 \mathrm{MW}$ total power generated, followed by the R11 (2.93 MW). The T-s diagrams of both R134A- and R11-based 
ORC are illustrated in Figure 6 for the thermodynamic comparison of the two cycles. It is also found in Table 4 that the power-generation difference between different working fluids is not significant. Considering the pumping work, the fluid R11 achieves the largest net power generation (2.52 MW) with the corresponding evaporation pressure of $0.48 \mathrm{MPa}$ and the condensation pressure of $0.13 \mathrm{MPa}$; while the fluid R134A requires higher pump work due to a much higher evaporation pressure (2.69 MPa, which leads to a net power output of $2.41 \mathrm{MW}$ ). Therefore, we consider the fluid R11 as the optimal. All the calculations and comparisons related to ORC are based on this fluid and its corresponding optimal working conditions.

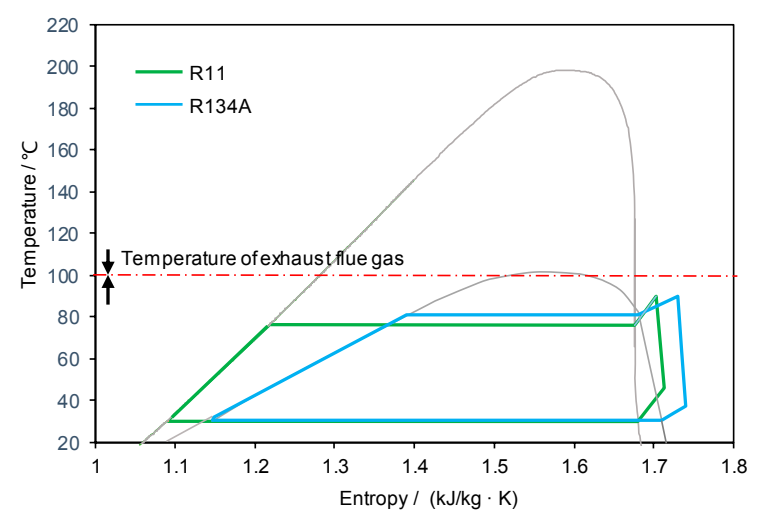

Figure 6. T-s diagrams of the ORCs with R11 and R134A.

\subsection{Exergy Analysis}

Compared with the original net power output (993.8 MW), an additional 23.99 MW, 6.49 MW, and 26.51 MW net power is produced with only in-depth boiler-turbine integration, only the ORC, and both the ORC and boiler-turbine integration. The in-depth boiler-turbine integration contributes the most to boost the power output, since the temperature level of flue gas up to $385^{\circ} \mathrm{C}$ has been considered for heat integration. The same decrease in the temperature difference of heat transfer, which is the driving force of the increase in power output, allows much more heat available for power generation, due to the wide temperature range of heat source. The additional work resulted from the utilization of the waste heat of flue gas from $135^{\circ} \mathrm{C}$ down to $75^{\circ} \mathrm{C}$ itself is limited no matter how small the heat-transfer temperature difference is reached. However, the ORC can still be employed with the in-depth boiler-turbine integration to reach a high-level waste heat recovery of the overall system.

The exergy analysis provides more insights on how each new integration concept eventually improves the system performance, with the comparison of exergy destructions within different components for different concepts in Figure 7. Due to the increased power output with the same amount of fuel consumption, the overall exergy efficiency of the system has been increased by 0.39 percentage points when only with ORC, 1.1 percentage point when only with the in-depth boiler-turbine integration, and 1.25 percentage point when with both concepts. It is also found in the in-depth turbine-boiler integration system that the reduction of the exergy destruction within the boiler subsystem reaches $27.75 \mathrm{MW}$, far larger than that within the turbine subsystem, $0.48 \mathrm{MW}$. Therefore, it is concluded that the energy-saving improvement is mainly contributed by the performance enhancement of the boiler subsystem. 


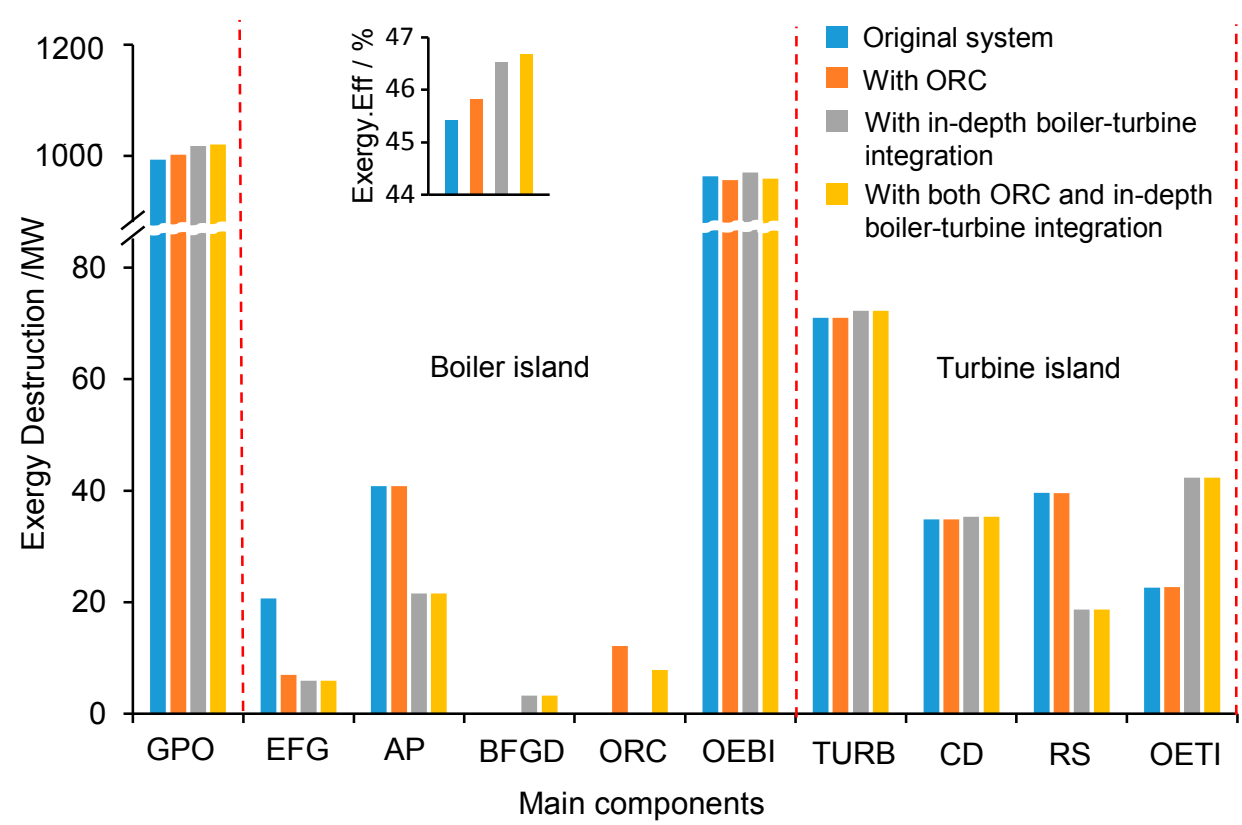

Figure 7. Exergy destruction distribution of main components for different integration concepts (GPO—gross power output, EFG—exhaust flue gas, AP—air preheating, BFGD—bypass flue gas duct, ORC—organic Rankine cycle, OEBI-other equipment of boiler island, TURB-Turbine, $\mathrm{CD}$ —condenser, RS—regenerative system, OETI—other equipment of turbine island).

More specifically, the decrease in exergy destruction within the boiler island is mainly due to the improvement of air preheating (AP), which reduces its exergy destruction from $40.77 \mathrm{MW}$ to 21.54 MW. This is mainly because of the utilization of the two-stage air preheater exchangers as well as the two-stage gas-water heater exchangers in the bypass flue gas duct (BFGD). The heat transfer temperature difference of the concept with both ORC and in-depth boiler-turbine integration decreases significantly due to the better temperature match of the hot and cold fluids after dividing the air preheating process into three parts. Although with the bypass flue-gas duct, the exergy destructions within the high-temperature gas-water heat exchangers and low-temperature gas-water heat exchangers increase by 2.38 and $0.86 \mathrm{MW}$, the system recovers $26.46 \mathrm{MW}$ exergy from the flue gas going through the bypass flue-gas duct. Therefore, the exergy destruction within the boiler island can be saved up to $27.75 \mathrm{MW}$ when with both ORC and in-depth boiler-turbine integration, and the exergy losses from flue gas (EFG) are largely reduced as well.

For the turbine island, the variations of the exergy destruction within the turbine (TURB) and condenser (CD) are rather small (only 1.66 MW), compared to that within the regenerative system (RS). The beauty of the in-depth boiler-turbine integration is that the new layout promotes some feedwater and condensate water acquiring heat from the flue gas via the two-stage gas-water heat exchangers configured in the bypass flue gas duct in the boiler island, which generally results in a significant reduction of the heat needed from the steam extractions and a boost of power output due to this suppress of steam extractions. The exergy destruction within the RS is reduced remarkably by 21.87 MW. However, the additional heat exchangers require much power to overcome the flow resistance, the exergy destruction within the other parts of the turbine (OETL), including the valves and pipeline, etc., increases also dramatically due to the pure power consumption, which eventually leads to an increase in total exergy destruction within the turbine island by $0.48 \mathrm{MW}$, compared to that of the original system.

For the ORC system, the exergy destructions are 13.26 MW and 8.19 WM for the systems with only the ORC and with both the ORC and the in-depth turbine-boiler interaction. The difference is 
mainly due to the different layouts of the ORC systems in both concepts, since there is two-stage evaporator for the former while one-stage evaporator for the latter.

More thermodynamic insights are given in Figure 8 to further illustrate how the system is improved with different integration concepts. With only one-stage of air-preheating, the mass flowrate and temperature of the air at an intermediate stage cannot be flexibly adjusted, which means the slopes of the two straight lines in Figure 8a are fixed. The upper-terminal temperature difference and the exergy destruction of the air preheater can be reduced by an increased air-preheater area; however, the increase in the final air-preheating temperature will increase the temperature of combustion, thus increasing the exergy destruction within the remaining boiler subsystem. This eventually increases the inlet temperature of the flue gas entering the air preheater. Therefore, increasing the air-preheater area is not a way of reasonably utilizing the heat at the boiler cold end. With the integration of only ORC (Figure $8 \mathrm{~b}$ ), there is no modification of the boiler subsystem at all. Only the heat of the flue gas at a temperature lower than $100{ }^{\circ} \mathrm{C}$ is utilized, which brings additional benefits without affecting the existing plant. However, the benefit is largely limited by the available heat extracted from the flue gas at a low temperature until the due temperature.

The essence of the in-depth boiler-turbine integration is given in Figure $8 \mathrm{c}$. With the splitting of the hot and cold fluids, the slopes of the Q-T profiles are in fact readily adjusted, which gives a much better opportunity for establishing better matches of temperature levels of heat transfer. Particularly, the temperature difference of the bypass flue gas duct can be reduced largely but still beyond the industrial minimum temperature difference usually employed. In addition, by the splitting of flue gas and multiple stages of air preheating, a smaller temperature difference for heat transfer can be successfully achieved without modifying the system too much. Further, coupling with the ORC system for ultra-low temperature waste heat allows for an even larger benefit can be achieved based on the in-depth boiler-turbine integration.

The grand composite curves of the varied parts of the four plants (Figure 8e) offers a much more straightforward comparison of the benefits from different concepts. With the in-depth boiler-turbine integration, the energy pocket enclosed by the flue gas is reduced significantly, which means more heat is extracted for better utilization (power generation). The pocket reduction realized by the ORC is also illustrated, although limited.

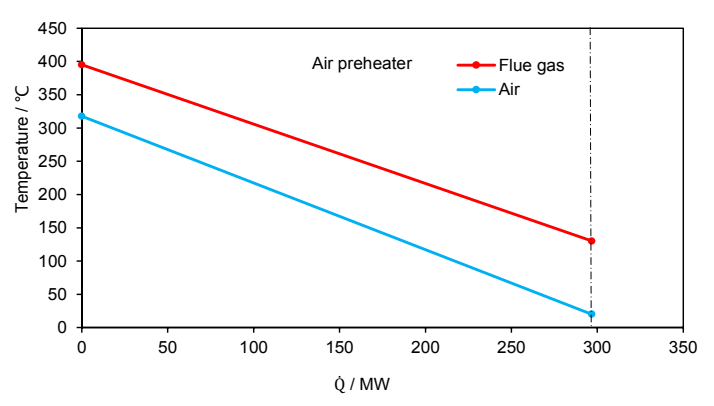

(a)

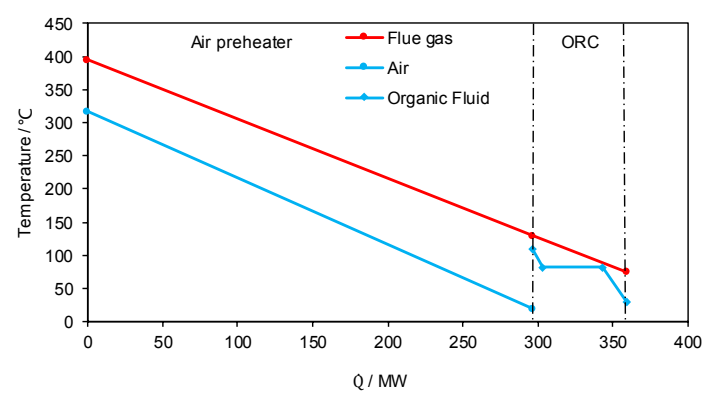

(b)

Figure 8. Cont. 


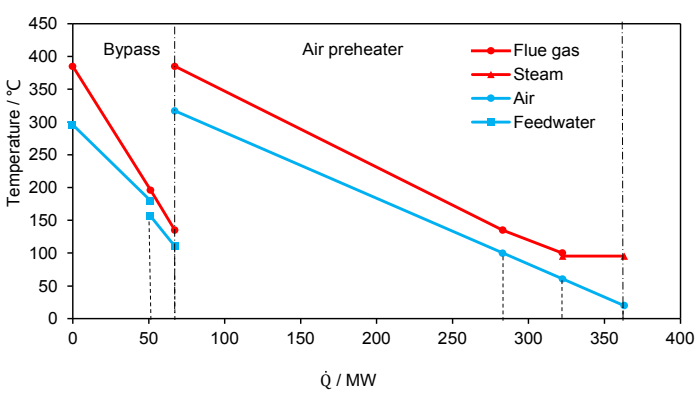

(c)

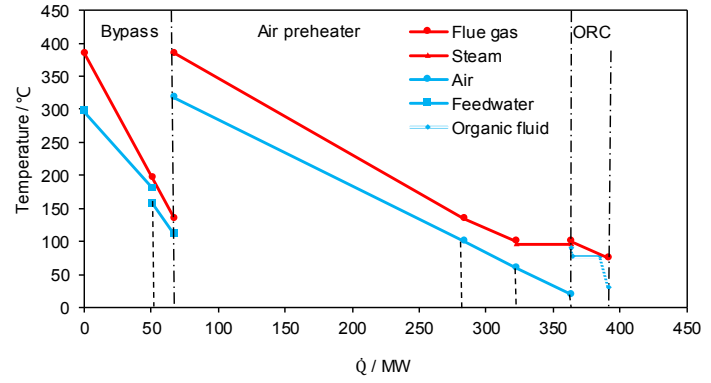

(d)

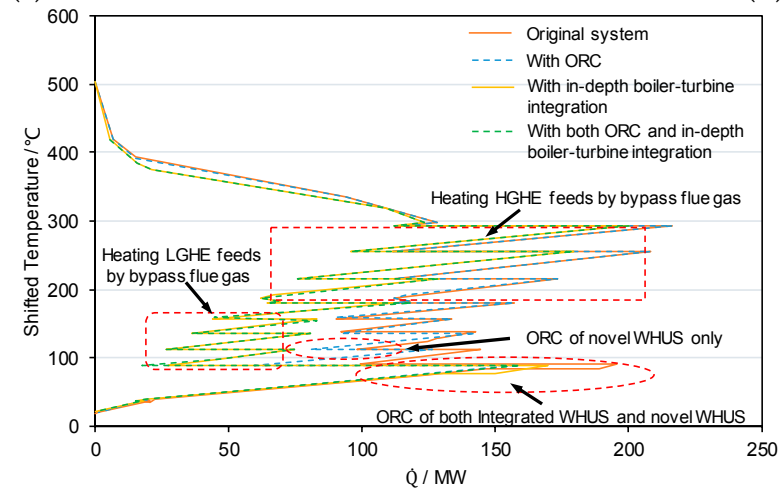

(e)

Figure 8. Thermodynamic insights on the system improvement of different integration concepts. (a) Original System; (b) The concept with only the ORC; (c) The concept with only the in-depth boiler-turbine integration; (d) The concept with both the ORC and in-depth boiler-turbine integration; (e) Grand composite curves of the varied parts of all four concepts.

\subsection{Economic Analysis}

The capital investment costs of the newly-added components of the three concepts are listed in Table 5. The additional capital investment cost introduced by the new components of in-depth turbine-boiler integration is 5.327 USD million, more than that of the ORC (3.951 USD million). The turbine and heat exchangers of the ORC contribute significantly to the total capital investment, leading to the fact that the potential of reducing the turbine cost and heat exchangers expense should be investigated. The integrated system with ORC and in-depth boiler-turbine integration needs the largest capital investment, 7.550 USD million, slightly less than the sum of both, due to the cost reduction of the equipment for the integrated system.

Table 5. The capital investment cost of the newly-added equipment (unit: million USD).

\begin{tabular}{cccc}
\hline Item & In-Depth Boiler-Turbine Integration & Only ORC & Integrated System \\
\hline High-temperature gas-water heat exchanger & 1.604 & - & 1.604 \\
Low-temperature gas-water heat exchanger & 0.886 & - & 0.886 \\
Second-stage heat exchanger & 0.985 & - & 0.985 \\
First-stage heat exchanger & 1.157 & - & 1.157 \\
Auxiliary equipments & 0.695 & - & 0.695 \\
Organic Rankine cycle evaporator & - & 1.429 & 0.661 \\
Organic Rankine cycle turbine & - & 1.132 & 0.646 \\
Organic Rankine cycle condenser & - & 0.355 & 0.720 \\
Organic Rankine cycle pump & 5.327 & 3.951 & 0.196 \\
Total investment cost & & & 7.550 \\
\hline
\end{tabular}

The economic feasibility of the three improved systems is further investigated by various economic indicators listed in Table 6. The EAI of the in-depth turbine-boiler integration is 7.317 million USD, three times more than that of the system with only the ORC (1.979 million USD). However, too many 
newly-added components, together with the high capital investment, increase the system reliability and complexity, which further results in an increased operation and maintenance cost. The EAI of the concept with only the ORC is 1.979 million USD with a $\mathrm{C}_{\mathrm{TCI}}$ of 1.462 million USD. Therefore, the system with only the ORC is less suggested to be applied solely at the current technology level. The NAR of the integrated system is 4.990 million USD, indicating its excellent economic performance and better implementation potential. The investment-payback period of the system with only the ORC is almost 2.26 years to recover the total investment, while the system with the in-depth boiler-turbine integration only needs 0.78 years. The single implementation of the ORC is less economically viable since large capital investment is needed for less gain in power output. This also indicates that the ORC technology is still quite expensive, and its economic competitiveness needs to be further enhanced by the technology developers. By integrating both concepts, the integrated system has an intermediate payback time of 1.01 years, which is still acceptable and may be helpful to promote the development and to reduce the cost of the ORC technology.

Table 6. Revenue analysis (units: MW, million USD and year).

\begin{tabular}{cccc}
\hline Item & In-Depth Boiler-Turbine Integration & Only ORC & Integrated System \\
\hline Net additional power output & 23.99 & 6.49 & 26.51 \\
Extra annual income (EAI) & 7.317 & 1.979 & 8.087 \\
Annualized investment capital cost (C $\left.\mathrm{C}_{\mathrm{TCI}}\right)$ & 1.971 & 1.462 & 2.794 \\
Operation \& maintenance cost $\left(\mathrm{C}_{\mathrm{O} \& \mathrm{M}}\right)$ & 0.213 & 0.158 & 0.302 \\
Net annual revenue (NAR) & 5.132 & 0.358 & 4.990 \\
Dynamic investment payback period (Pt) & 0.78 & 2.26 & 1.01 \\
\hline
\end{tabular}

\section{Conclusions}

In this paper, as a follow-up to our previous research, we proposed a novel waste heat recovery system based on a comprehensive understanding of the ORC and in-depth system integration. Then, we comparatively evaluated three integration concepts of the large-scale coal-fired power plant to better utilize the heat at an overall system level, particularly that at intermediate and low grade. The three concepts employ only ORC, only in-depth boiler-turbine integration, and both, respectively. A comprehensive and comparative evaluation of these three concepts is performed in terms of thermodynamic and economic performances to evaluate their feasibility and competitiveness. The major conclusions are as follows:

For the in-depth boiler-turbine integration system, by splitting the flue gas, the heat capacities of the hot streams can be adjusted to have a better match with available cold streams, thus fulfilling much better overall heat integration. Therefore, the multi-stage air preheating is made possible and significantly reduces the heat-transfer temperature difference. The exergy destruction of the air preheating process is reduced by 19.23 MW. By introducing this part of flue-gas heat to the turbine system, the steam extractions can be largely suppressed, thus largely boosting the power output. The in-depth boiler-turbine integration demonstrated an additional power output of 23.99 MW and high economic competitiveness (with a payback time of only 0.78 years).

The selection of the working fluid with respect to available heat sources is important to maximize the ORC performance. The best ORC working fluid found out of eight for the given flue gas temperature $\left(100^{\circ} \mathrm{C}\right)$ is $\mathrm{R} 11$, which can be fully vaporized at such a low temperature and, therefore, offer better work ability. With the utilization of its latent heat, the mass flowrate of R11 in the ORC is much lower than those of the other working fluids. With R11-based ORC, the exergy loss from the exhausted flue gas is reduced from 20.69 MW to 5.90 MW, which results in an additional power output of 6.49 MW.

Compared with in-depth boiler-turbine integration, the waste heat recovery via ORC only delivers limited effect to further increase the power output; however, its high investment cost and lower payback time make its single application hardly acceptable in a near term. However, by coupling the ORC with 
in-depth boiler-turbine integration, the payback time can be largely reduced, indicating a better choice to promote the large-scale deployment of ORC and cost reduction.

Acknowledgments: The authors, Shengwei Huang, Chengzhou Li, Tianyu Tan and Yongping Yang, receive financial support from the National Major Fundamental Research Program of China No. (2011CB710706), the National Nature Science Fund of China (No. 51025624), the 111 Project (B12034), the Fundamental Research Funds for the Central Universities (No. 2014ZD04). The authors appreciate the critical comments from all four reviewers, particularly the expert insights on the ORC part from the third reviewer.

Author Contributions: Shengwei Huang, Ligang Wang and Yongping Yang conceived and designed the various integration concepts; Shengwei Huang and Chengzhou Li performed the thermo-economic analysis; Tianyu Tan and Peng Fu contributed to the writing; Shengwei Huang completed the main tasks for the work reported.

Conflicts of Interest: The authors declare no conflict of interest.

\section{Abbreviations}

\begin{tabular}{|c|c|}
\hline WHUS & Waste heat recovery system \\
\hline ORC & Organic Rankine Cycle \\
\hline PPTD & Pinch Point Temperature Difference \\
\hline EPC & Electricity Production Cost \\
\hline $\mathrm{RH}$ & Regenerative heater \\
\hline LTEs & Low-temperature economizers \\
\hline THA & The design condition \\
\hline HPT & High-pressure turbine \\
\hline IPT & Intermediate-pressure turbine \\
\hline LPT & Low-pressure turbine \\
\hline HGHE & High-Temperature Gas-water heat exchanger \\
\hline LGHE & Low-Temperature Gas-water heat exchanger \\
\hline FSHE & First-stage heat exchanger \\
\hline SSHE & Second-stage heat exchanger \\
\hline ESP & Electrostatic precipitator \\
\hline FGD & Flue gas desulfurization \\
\hline NAR & The net annual revenue \\
\hline ORCE & Organic Rankine Cycle Evaporator \\
\hline ORCT & Organic Rankine Cycle Turbine \\
\hline ORCC & Organic Rankine Cycle Condenser \\
\hline HHV & Higher heating value \\
\hline O\&M & Operation and maintenance \\
\hline CEPCI & Chemical Engineering Plant Cost Index \\
\hline Pt & Dynamic investment pay-back period \\
\hline GPO & Gross power output \\
\hline EFG & Exhaust Flue Gas \\
\hline $\mathrm{AP}$ & Air Preheating \\
\hline BFGD & Bypass Flue Gas Duct \\
\hline OEBI & Other Equipment of Boiler Island \\
\hline TURB & Turbine \\
\hline CD & Condenser \\
\hline RS & Regenerative System \\
\hline OETI & Other Equipment of Turbine Island \\
\hline TIC & Total investment capital \\
\hline EAI & Extra annual income \\
\hline
\end{tabular}




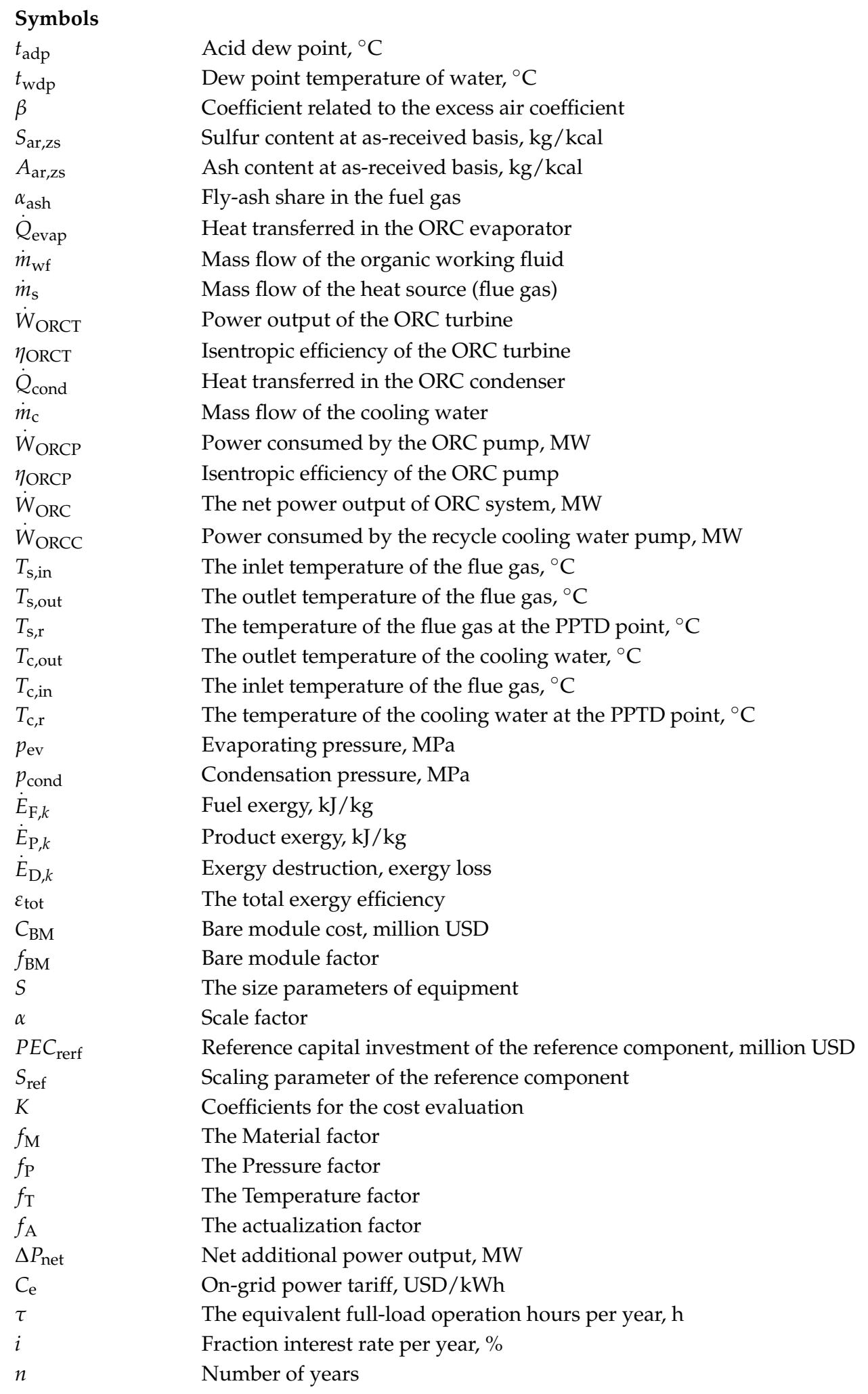

\section{References}

1. China Electricity Council. Annual Development Report of China Power Industry; China Market Press: Beijing, China, 2017. (In Chinese)

2. Wang, L. Thermo-Economic Evaluation, Optimization and Synthesis of Large-Scale Coal-Fired Power Plants. Ph.D. Thesis, Technische Universität Berlin, Berlin, Germany, 2016. 
3. Fukuda, Y. Development of Advanced Ultra Supercritical Fossil Power Plants in Japan: Materials and High Temperature Corrosion Properties. Mater. Sci. Forum 2011, 696, 236-241. [CrossRef]

4. Technology Roadmap: High-Efficiency, Low-Emissions Coal-Fired Power Generation. 2012. Available online: www.environmentportal.in/content/367588/technology-roadmap-high-efficiency-low-emissionscoal-fired-power-generation/ (accessed on 25 January 2018).

5. Masuyama, F. Alloy development and material issues with increasing steam temperature. In Advances in Materials Technology for Fusion Power Plants_Proceedings from Fourth International Conference; ASM International: Cleveland, OH, USA, 2004.

6. Huseman, R. Advanced $\left(700^{\circ} \mathrm{C}\right)$ PF power plant: A clean coal European technology. In Advanced Material for AD700 Boilers; Cesi Auditorium: Milano, Italy, 2005.

7. Viswanathan, R.; Coleman, K.; Rao, U. Materials for ultra-supercritical coal-fired power plant boilers. Int. J. Press. Vessel. Pip. 2006, 83, 778-783. [CrossRef]

8. Weitzel, P.S. Steam Generator for Advanced Ultra Supercritical Power Plants $700{ }^{\circ} \mathrm{C}$ to $760^{\circ} \mathrm{C}$. In Proceedings of the ASME 2011 Power Conference Collocated with Jsme Icope, Denver, CO, USA, 12-14 July 2011; pp. 281-291.

9. Kjaer, S.; Drinhaus, F. A Modified Double Reheat Cycle. In Proceedings of the ASME 2010 Power Conference, Chicago, IL, USA, 13-15 July 2010; pp. 285-293.

10. Karthikeyan, M.; Wu, Z.; Mujumdar, A.S. Low-rank coal drying technologies-Current status and new developments. Dry. Technol. 2009, 27, 403-415. [CrossRef]

11. Yang, Y.; Du, X.; Li, J. Advance in Fundamental Research on Energy Conservation of Large-Scale Coal-Fired Power Generating Unit. China Basic Sci. 2013, 3, 30-34. (In Chinese)

12. Blum, R.; Kjaer, S.; Bugge, J. Development of a PF Fired High Efficiency Power Plant (AD700). In Proceedings of the Riso International Energy Conference (Energy Solutions for Sustainable Development), Roskilde, Denmark, 22-24 May 2007; pp. 69-80.

13. Stepczyńska, K.; Kowalczyk, L.; Dykas, S.; Elsner, W. Calculation of a $900 \mathrm{MW}$ conceptual $700 / 720{ }^{\circ} \mathrm{C}$ coal-fired power unit with an auxiliary extraction-backpressure turbine. J. Power Technol. 2012, 92, 266.

14. Huang, S. Energy Saving Analysis and Comprehensive Optimization of the Boiler Flue Gas Heat Recovery in Large Scale Coal-Fired Unit. Master's Thesis, North China Electric Power University, Beijing, China, 2013. (In Chinese)

15. Shi, X.; Che, D. Thermodynamic analysis of an LNG fueled combined cycle power plant with waste heat recovery and utilization system. Int. J. Energy Res. 2007, 31, 975-998. [CrossRef]

16. Yu, H.; Xu, G.; Yang, Y.; Li, Y. A clean and efficient waste heat utilization system in coal-fired power plants. Proc. CSEE 2016, 36. (In Chinese) [CrossRef]

17. Bi, Q.; Ma, Y.; Bai, Z. Simulation in Aspen Plus of Power Plant's Circulating Water Waste Heat Recovery System. In Proceedings of the IEEE International Conference on E-Product E-Service and E-Entertainment, Henan, China, 7-9 November 2010; pp. 1-4.

18. Hwang, K.; Song, C.H.; Saito, K.; Kawai, S. Experimental study on titanium heat exchanger used in a gas fired water heater for latent heat recovery. Appl. Therm. Eng. 2010, 30, 2730-2737. [CrossRef]

19. Tchanche, B.F.; Lambrinos, G.; Frangoudakis, A.; Papadakis, G. Low-grade heat conversion into power using organic Rankine cycles-A review of various applications. Renew. Sustain. Energy Rev. 2011, 15, 3963-3979. [CrossRef]

20. Ziółkowski, P.; Kowalczyk, T.; Kornet, S.; Badur, J. On low-grade waste heat utilization from a supercritical steam power plant using an ORC-bottoming cycle coupled with two sources of heat. Energy Convers. Manag. 2017, 146, 158-173. [CrossRef]

21. Borsukiewiczgozdur, A. Influence of heat recuperation in ORC power plant on efficiency of waste heat utilization. Arch. Thermodyn. 2010, 31, 111-123.

22. Amini, A.; Mirkhani, N.; Pourfard, P.P.; Ashjaee, M.; Khodkar, M.A. Thermo-economic optimization of low-grade waste heat recovery in Yazd combined-cycle power plant (Iran) by a $\mathrm{CO}_{2}$, trans-critical Rankine cycle. Energy 2015, 86, 74-84. [CrossRef]

23. Coskun, U.C.; Brenner, M.; Hymel, T.; Vakaryuk, V.; Levchenko, A.; Bezryadin, A. Flue gas purification and heat recovery: A biomass fired boiler supplied with an open absorption system. Appl. Energy 2012, 96, 444-450. 
24. Wang, D.; Bao, A.; Kunc, W.; Liss, W. Coal power plant flue gas waste heat and water recovery. Appl. Energy 2012, 91, 341-348. [CrossRef]

25. Wang, C.; He, B.; Sun, S.; Wu, Y.; Yan, N.; Yan, L.; Pei, X. Application of a low pressure economizer for waste heat recovery from the exhaust flue gas in a $600 \mathrm{MW}$ power plant. Energy 2012, 48, 196-202. [CrossRef]

26. Wang, C.; He, B.; Yan, L.; Pei, X.; Chen, S. Thermodynamic analysis of a low-pressure economizer based waste heat recovery system for a coal-fired power plant. Energy 2014, 65, 80-90. [CrossRef]

27. Huang, S.; Li, C.; Tan, T.; Fu, P.; Xu, G.; Yang, Y. An Improved System for Utilizing Low-Temperature Waste Heat of Flue Gas from Coal-Fired Power Plants. Entropy 2017, 19, 423. [CrossRef]

28. Oluleye, G.; Jobson, M.; Smith, R.; Perry, S. Evaluating the Potential of a Process Site for Waste Heat Recovery. Appl. Energy 2016, 161, 627-646. [CrossRef]

29. Campana, F.; Bianchi, M.; Branchini, L.; Pascale, A.D.; Peretto, A.; Baresi, M.; Fermi, A.; Rossetti, N.; Vescovo, R. ORC waste heat recovery in European energy intensive industries: Energy and GHG savings. Energy Convers. Manag. 2013, 76, 244-252. [CrossRef]

30. Cavazzini, G.; Toso, P.D. Techno-economic feasibility study of the integration of a commercial small-scale ORC in a real case study. Energy Convers. Manag. 2015, 99, 161-175. [CrossRef]

31. Pierobon, L.; Benato, A.; Scolari, E.; Haglind, F.; Stoppato, A. Waste heat recovery technologies for offshore platforms. Appl. Energy 2014, 136, 228-241. [CrossRef]

32. Li, Y.R.; Wang, J.N.; Du, M.T. Influence of coupled pinch point temperature difference and evaporation temperature on performance of organic Rankine cycle. Energy 2012, 42, 503-509. [CrossRef]

33. Roy, J.P.; Mishra, M.K.; Misra, A. Parametric optimization and performance analysis of a waste heat recovery system using organic Rankine cycle. Energy 2010, 35, 5049-5062. [CrossRef]

34. Li, Y.R.; Du, M.T.; Wu, C.M.; Wu, S.Y.; Liu, C.; Xu, J.L. Economical evaluation and optimization of subcritical organic Rankine cycle based on temperature matching analysis. Energy 2014, 68, 238-247. [CrossRef]

35. Kermani, A.; Wallerand, A.S.; Kantor, I.D.; Maréchal, F. Generic superstructure synthesis of organic Rankine cycles for waste heat recovery in industrial processes. Appl. Energy 2018, 212, 1203-1225. [CrossRef]

36. Zhou, N.; Wang, X.; Chen, Z.; Wang, Z. Experimental study on organic Rankine cycle for waste heat recovery from low-temperature flue gas. Energy 2013, 55, 216-225. [CrossRef]

37. Xue, X.; Guo, C.; Du, X.; Yang, L.; Yang, Y. Thermodynamic analysis and optimization of a two-stage organic rankine cycle for liquefied natural gas cryogenic exergy recovery. Energy 2015, 83, 778-787. [CrossRef]

38. Hung, T.C. Waste heat recovery of organic Rankine cycle using dry fluids. Energy Convers. Manag. 2001, 42, 539-553. [CrossRef]

39. Cavazzini, G.; Bari, S.; Pavesi, G.; Ardizzon, G. A multi-fluid PSO-based algorithm for the search of the best performance of sub-critical organic rankine cycles. Energy 2017, 129, 42-58. [CrossRef]

40. Pezzuolo, A.; Benato, A.; Stoppato, A.; Mirandola, A. The ORC-PD: A versatile tool for fluid selection and organic Rankine cycle unit design. Energy 2016, 102, 605-620. [CrossRef]

41. Branchini, L.; Pascale, A.D.; Peretto, A. Systematic comparison of ORC configurations by means of comprehensive performance indexes. Appl. Therm. Eng. 2013, 61, 129-140. [CrossRef]

42. Stoppato, A. Energetic and economic investigation of the operation management of an organic Rankine cycle cogeneration plant. Energy 2012, 41, 3-9. [CrossRef]

43. Xu, G.; Xu, C.; Yang, Y.; Fang, Y.; Li, Y.; Song, X. A novel flue gas waste heat recovery system for coal-fired ultra-supercritical power plants. Appl. Therm. Eng. 2014, 67, 240-249. [CrossRef]

44. Xu, G.; Huang, S.; Yang, Y.; Wu, Y.; Zhang, K.; Xu, C. Techno-economic analysis and optimization of the heat recovery of utility boiler flue gas. Appl. Energy 2013, 112, 907-917. [CrossRef]

45. Yang, Z. The Temporal-spacial Distribution of Energy Consumption and Energy Saving of Large Coal-Fired Power Units. Ph.D. Thesis, North China Electric Power University, Beijing, China, 2013.

46. Rukes, B.; Taud, R. Status and perspectives of fossil power generation. Energy 2004, 29, 1853-1874. [CrossRef]

47. Spliethoff, H. Steam Power Stations for Electricity and Heat Generation. In Power Generation from Solid Fuels; Springer: Berlin, Germany, 2010.

48. Wang, L.; Lampe, M.; Voll, P.; Yang, Y.; Bardow, A. Multi-objective superstructure-free synthesis and optimization of thermal power plants. Energy 2016, 116, 1104-1116. [CrossRef]

49. Wang, L.; Voll, P.; Lampe, M.; Yang, Y.; Bardow, A. Superstructure-free synthesis and optimization of thermal power plants. Energy 2015, 91, 700-711. [CrossRef] 
50. Song, J.; Kan, W.; Xu, C.; Xu, G.; Song, X. Comprehensive optimization of air preheater for boiler flue gas heat recovery. J. Chin. Soc. Power Eng. 2014, 34, 140-146.

51. Wei, M.; Zhao, X.; Fu, L.; Zhang, S. Performance study and application of new coal-fired boiler flue gas heat recovery system. Appl. Energy 2017, 188, 121-129. [CrossRef]

52. Jin, H.; Hong, H.; Wang, B.; Han, W.; Lin, R. A new principle of synthetic cascade utilization of chemical energy and physical energy. Sci. China Ser. Eng. Mater. Sci. 2005, 48, 163-179. [CrossRef]

53. Stehlik, P. Heat transfer as an important subject in waste-to-energy systems. Appl. Therm. Eng. 2007, 27, 1658-1670. [CrossRef]

54. Han, X.; Liu, M.; Wang, J.; Yan, J.; Liu, J.; Xiao, F. Simulation study on lignite-fired power system integrated with flue gas drying and waste heat recovery-Performances under variable power loads coupled with off-design parameters. Energy 2014, 76, 406-418. [CrossRef]

55. Chen, Q.; Finney, K.; Li, H.N.; Zhang, X.H.; Zhou, J.; Sharifi, V.; Swithenbank, J. Condensing boiler applications in the process industry. Appl. Energy 2012, 89, 30-36. [CrossRef]

56. Yang, Y.; Xu, C.; Xu, G.; Han, Y.; Fang, Y.; Zhang, D. A new conceptual cold-end design of boilers for coal-fired power plants with waste heat recovery. Energy Convers. Manag. 2015, 89, 137-146. [CrossRef]

57. Kotowicz, J.; Michalski, S. Thermodynamic and economic analysis of a supercritical and an ultra-critical oxy-type power plant without and with waste heat recovery. Appl. Energy 2016, 179, 806-820. [CrossRef]

58. Wang, L.; Fu, P.; Wang, N.; Morosuk, T.; Yang, Y.; Tsatsaronis, G. Malfunction diagnosis of thermal power plants based on advanced exergy analysis: The case with multiple malfunctions occurring simultaneously. Energy Convers. Manag. 2017, 148, 1453-1467. [CrossRef]

59. Wang, L.; Yang, Y.; Dong, C.; Morosuk, T.; Tsatsaronis, G. Parametric optimization of supercritical coal-fired power plants by MINLP and differential evolution. Energy Convers. Manag. 2014, 85, 828-838. [CrossRef]

60. Wang, L.; Yang, Y.; Dong, C.; Yang, Z.; Xu, G.; Wu, L. Exergoeconomic evaluation of a modern ultra-supercritical power plant. Energies 2012, 5, 3381-3397. [CrossRef]

61. Li, X.; Wang, N.; Wang, L.; Kantor, I.; Robineau, J-L.; Yang, Y.; Maréchal, F. A data-driven model for the air-cooling condenser of thermal power plants based on data reconciliation and support vector regression. Appl. Therm. Eng. 2018, 129, 1496-1507. [CrossRef]

62. Li, X.; Wang, N.; Wang, L.; Yang, Y.; Maréchal, F. Identification of optimal operating strategy of direct air-cooling condenser for Rankine cycle based power plants. Appl. Energy 2018, 209, 153-166. [CrossRef]

63. Fu, P.; Wang, N.; Wang, L.; Morosuk, T.; Yang, Y.; Tsatsaronis, G. Performance Degradation Diagnosis of Thermal Power Plants: A Method based on Advanced Exergy Analysis. Energy Convers. Manag. 2016, 130, 219-229. [CrossRef]

64. Bahadori, A. Estimation of combustion flue gas acid dew point during heat recovery and efficiency gain. Appl. Therm. Eng. 2011, 31, 1457-1462. [CrossRef]

65. Li, Z.C. The analysis of the in-depth utilization of flue gas waste heat in power plant. Wirel. Internet Technol. 2013, 6, 84-85. (In Chinese)

66. Xiang, B.; Tang, B.; Wu, Y.; Yang, H.; Zhang, M.; Lu, J. Predicting acid dew point with a semi-empirical model. Appl. Therm. Eng. 2016, 106, 992-1001. [CrossRef]

67. Jiang, A.Z.; Wang, G.; Shi, S.Y.; Zheng, S.H. Discussion on Calculation Formulae of Boiler's Acid Dew-Point Temperature of Gas. Boiler Technol. 2009, 40, 11-13. (In Chinese)

68. Han, Y.; Xu, G.; Yang, Y.; Xu, C.; Song, X. An optimized system for clean, efficient and deep utilization of flue gas waste heat from coal-fired power plants. J. Chin. Soc. Power Eng. 2015, 35, 674-680.

69. EBSILON Professional Version 13 by STEAG Energy Services GmbH, Zwingenberg, Germany. 2017. Available online: www.ebsilon.com (accessed on 3 December 2017).

70. Nguyen, T.Q.; Slawnwhite, J.D.; Boulama, K.G. Power generation from residual industrial heat. Energy Convers. Manag. 2010, 51, 2220-2229. [CrossRef]

71. Wang, L.; Yang, Y.; Morosuk, T.; Tsatsaronis, G. Advanced Thermodynamic Analysis and Evaluation of a Supercritical Power Plant. Energies 2012, 5, 1850-1863. [CrossRef]

72. Wu, L.; Wang, L.; Wang, Y.; Hu, X.; Dong, C.; Yang, Z.; Yang, Y. Component and process based exergy evaluation of a $600 \mathrm{MW}$ coal-fired power plant. Energy Procedia 2014, 61, 2097-2100. [CrossRef]

73. Yang, Y.; Wang, L.; Dong, C.; Xu, G.; Morosuk, T.; Tsatsaronis, G. Comprehensive exergy-based evaluation and parametric study of a coal-fired ultra-supercritical power plant. Appl. Energy 2013, 112, 1087-1099. [CrossRef] 
74. Wang, L.; Yang, Y.; Dong, C.; Morosuk, T.; Tsatsaronis, G. Systematic optimization of the design of steam cycles using minlp and differential evolution. J. Energy Resour. Technol. 2014, 136, 031601. [CrossRef]

75. Wang, L.; Yang, Y.; Dong, C.; Gang, X.U. Improvement and primary application of theory of fuel specific consumption. Proc. CSEE 2012, 32, 16-21.

76. Wang, L.; Wu, L.; Xu, G.; Dong, C.; Yang, Y. Calculation and analysis of energy consumption interactions in thermal systems of large-scale coal-fired steam power generation units. Proc. CSEE 2012, 32, 9-14.

77. Fu, P. Diagnosis Methods Based on Tempospacial Energy-Saving Effect in Large Scale Coal-Fired Power Plants. Ph.D. Thesis, North China Electric Power University, Beijing, China, 2017.

78. Huang, J. Diffusion entropy analysis based on empirical mode decomposition. J. Beijing Inf. Sci. Technol. Univ. 2015, 30, 53-56. (In Chinese)

79. Kreutz, T.; Williams, R.; Consonni, S.; Chiesa, P. Co-production of hydrogen, electricity and $\mathrm{CO}_{2}$, from coal with commercially ready technology. Part B: Economic analysis. Int. J. Hydrog. Energy 2003, 30, 769-784. [CrossRef]

80. Strömberg, L.; Lindgren, G.; Jacoby, J.; Giering, R.; Anheden, M.; Burchhardt, U.; Altmann, H.; Kluger, F.; Stamatelopoulos, G.N. Update on Vattenfall's 30 MWth oxy-fuel pilot plant in Schwarze Pumpe. Energy Procedia 2009, 1, 581-589. [CrossRef]

81. Turton, R.; Bailie, R.C.; Whiting, W.B.; Shaeiwitz, J.A. Analysis, Synthesis and Design of Chemical Processes, 3rd ed.; Prentice-Hall: Upper Saddle River, NJ, USA, 2009.

82. Espatolero, S.; Cortés, C.; Romeo, L.M. Optimization of boiler cold-end and integration with the steam cycle in supercritical units. Appl. Energy 2010, 87, 1651-1660. [CrossRef]

83. Xi, H.; Li, M.; He, Y.; Zhang, Y. Economical evaluation and optimization of organic Rankine cycle with mixture working fluids using R245fa as flame retardant. Appl. Therm. Eng. 2017, 113, 1056-1070. [CrossRef]

84. Guo, T.; Wang, H.X.; Zhang, S.J. Fluids and parameters optimization for a novel cogeneration system driven by low-temperature geothermal sources. Energy 2011, 36, 2639-2649. [CrossRef]

85. Cayer, E.; Galanis, N.; Nesreddine, H. Parametric study and optimization of a trans-critical power cycle using a low temperature source. Appl. Energy 2010, 87, 1349-1357. [CrossRef]

86. Zhao, M.; Minett, A.I.; Harris, A.T. A review of techno-economic models for the retrofitting of conventional pulverised-coal power plants for Post-Combustion Capture (PCC) of $\mathrm{CO}_{2}$. Energy Environ. Sci. 2013, 6, $25-40$. [CrossRef]

87. Ji, Z. The discussion of the calculation method of dynamic investment recovery period. BioTech World 2012, 19, 142. (In Chinese) 